\title{
PENGARUH ALIRAN MODAL SWASTA JANGKA PENDEK TERHADAP PERUBAHAN NILAI TUKAR RUPIAH DAN LAJU INFLASI DI INDONESIA PERIODE 1990.I - 2000.IV
}

\author{
Oleh: \\ Rahadian Agus Hamdani*)
}

\begin{abstract}
ABSTRAK
Aliran modal swasta jangka pendek merupakan salah satu sumber pembiayaan bagi negaranegara yang sedang berkembang. Disisi lain, aliran modal dapat mempengaruhi nilai tukar dan laju inflasi. Berdasarkan hal tersebut, maka dilakukan penelitian dengan judul: "Pengaruh Aliran Modal Swasta Jangka Pendek Terhadap Perubahan Nilai Tukar Rupiah dan Laju Inflasi Di Indonesia Periode 1990.I - 2000.IV".

Tujuan dari penelitian ini ialah untuk menganalisis keterkaitan antara aliran modal swasta jangka pendek dan faktor-faktor yang mempengaruhi nilai tukar dan laju inflasi menggunakan pendekatan moneter. Metode analisis yang digunakan dalam penelitian ini ialah persamaan simultan dengan pendekatan Two Stage Least Squares (TSLS).

Kenyataan yang terjadi di Indonesia selama periode penelitian ialah aliran modal swasta jangka pendek sangat dipengaruhi oleh perubahan nilai tukar yang fluktuatif. Hal ini mengindikasikan bahwa Indonesia hanya menjadi objek spekulatif para spekulan valuta asing. Sedangkan nilai tukar rupiah sendiri dipengaruhi secara signifikan oleh aliran modal swasta jangka pendek, laju inflasi dan impor ditambah defisit neraca jasa. Dari kenyataan ini bisa diambil kesimpulan bahwa aliran modal swasta jangka pendek memiliki hubungan yang timbal balik dengan perubahan nilai tukar rupiah. Terakhir laju inflasi secara signifikan dipengaruhi oleh aliran modal swasta jangka pendek, perubahan nilai tukar dan tingkat suku bunga sertifikat Bank Indonesia. Sedangkan perubahan produk domestik bruto riil walaupun mempengaruhi inflasi secara signifikan, tetapi memiliki arah yang berlawanan dengan teori yang ada. Di duga hal ini berhubungan dengan pesimisme masyarakat terhadap inflasi di masa yang akan datang.
\end{abstract}

*) Mahasiswa Universitas Padjajaran, Bandung 


\section{PENDAHULUAN}

Cejalan dengan perkembangan ekonomi internasional yang semakin pesat, dimana Ohubungan ekonomi antar negara juga semakin saling terkait (adanya saling ketergantungan antar negara), telah mengakibatkan peningkatan arus perdagangan barang maupun uang serta modal antar negara. Meningkatnya aliran modal pada awal tahun 1990-an, terutama ke negara-negara yang sedang berkembang, antara lain didorong oleh peningkatan kapitalisasi pasar keuangan, pertumbuhan ekonomi yang relatif tinggi (yang menunjukkan adanya potensi permintaan pasar atas produk-produk yang dihasilkan) dan suku bunga tinggi (sebagai upaya investor asing dalam mencari high return suku bunga), karena suku bunga di negara-negara maju umumnya relatif lebih rendah.

Pesatnya aliran modal tersebut juga merupakan upaya untuk melakukan diversifikasi risiko oleh investor. Hal tersebut dilakukan dalam rangka menghadapi ketidakpastian dari adanya gejolak ekonomi, sosial dan politik di berbagai negara, sehingga para investor dapat terhindar atau meminimalkan risiko dalam menginvestasikan dananya.

Bagi negara-negara yang sedang berkembang, pesatnya aliran modal merupakan kesempatan guna memperoleh dana pembiayaan pembangunan ekonomi. Pentingnya hal tersebut mengingat masih terbatasnya tabungan dalam negeri negara-negara yang sedang berkembang sebagai sumber pembiayaan kebutuhan investasi.

Indonesia adalah negara berkembang yang memiliki sistem perekonomian terbuka. Perekonomian yang terbuka ini memungkinkan kondisi perekonomian di Indonesia mendapat pengaruh dari luar negeri selain pengaruh dari dalam negeri sendiri. Gejolakgejolak yang terjadi di dunia internasional berupa perubahan tingkat harga, tingkat suku bunga maupun nilai tukar dan inflasi akan berpengaruh terhadap kondisi perekonomian Indonesia.

Tabel 1.1

Perkembangan Aliran Penanaman Modal Langsung (APML)

Tahun 1990 - 2000

\begin{tabular}{|c|c|c|c|}
\hline Periode & $\begin{array}{c}\text { APML } \\
\text { Juta US \$ }\end{array}$ & Periode & $\begin{array}{c}\text { APML } \\
\text { Juta US \$ }\end{array}$ \\
\hline 1990 & $\mathbf{1 0 9 3}$ & 1995 & $\mathbf{4 3 4 6}$ \\
1991 & $\mathbf{1 4 8 2}$ & 1996 & $\mathbf{6 1 9 4}$ \\
1992 & $\mathbf{1 7 7 7}$ & 1998 & $\mathbf{4 6 7 7}$ \\
1993 & $\mathbf{2 0 0 4}$ & 1999 & $\mathbf{- 3 5 6}$ \\
1994 & $\mathbf{2 1 0 9}$ & 2000 & $\mathbf{- 2 7 4 5}$ \\
\hline
\end{tabular}

Sumber : International Financial Statistics. 
Salah satu faktor yang berpengaruh pada perubahan nilai tukar rupiah dan inflasi adalah aliran modal swasta jangka pendek ke Indonesia. Perubahan aliran modal swasta jangka pendek ini berakibat pada perubahan nilai tukar rupiah terhadap mata uang asing.

Derasnya aliran modal masuk (capital inflow) ke Indonesia, khususnya modal swasta penanaman modal jangka pendek, dapat ditunjukkan pada gambar 1.1, selama periode 1990 sampai dengan pertengahan 1997 (yang merupakan periode high capital inflow) selalu positif dan mengalami peningkatan dengan pertumbuhan rata-rata per tahun sebesar 24,92 persen. Pada tahun 1990 aliran modal swasta bernilai US \$ 1,000 juta, yang terdiri atas penanaman modal langsung (foreign direct investment) senilai US \$ 1,093 juta dan penanaman modal jangka pendek sebesar US \$-93 juta. Selanjutnya pada tahun 1996 nilai aliran modal swasta sebesar US $\$ 11,199$ juta, yang terdiri atas penanaman modal langsung US $\$ 6,194$ juta dan penanaman modal jangka pendek US $\$ 5,005$ juta.

Tabel 1.2

Penanaman Modal Jangka Pendek (PMJP) di Indonesia,

Tahun 1990 - 2000

\begin{tabular}{|c|c|c|c|}
\hline Periode & $\begin{array}{c}\text { PMJP } \\
\text { Juta US \$ }\end{array}$ & Periode & $\begin{array}{c}\text { PMJP } \\
\text { Juta US \$ }\end{array}$ \\
\hline & & 1995 & $\mathbf{4 1 0 0}$ \\
1990 & $\mathbf{- 9 3}$ & 1996 & $\mathbf{5 0 0 5}$ \\
1991 & $\mathbf{- 1 2}$ & 1997 & $\mathbf{- 2 6 3 2}$ \\
1992 & $\mathbf{- 8 8}$ & 1998 & $\mathbf{- 6 4 5 0}$ \\
1993 & $\mathbf{1 8 0 5}$ & 1999 & $\mathbf{- 4 7 1 0}$ \\
1994 & $\mathbf{3 8 7 7}$ & 2000 & $\mathbf{- 5 1 6 9}$ \\
\hline
\end{tabular}

Sumber : International Financial Statistics.

Ketika krisis moneter melanda Thailand pada bulan Mei 1997 dan menimbulkan efek penularan (contangion effect) terhadap Indonesia pada bulan Juli 1997, yang ditandai oleh terjadinya aliran modal keluar (capital outflow) secara mendadak dalam jumlah yang besar. Hal tersebut dapat ditunjukkan bahwa pada pertengahan tahun 1997 (awal krisis moneter di Indonesia) aliran modal swasta bernilai negatif sebesar US \$ -2045 juta, terdiri atas penanaman modal langsung sebesar US $\$ 4,677$ juta dan penanaman modal jangka pendek senilai US \$ -2,632 juta. Pada tahun 1998 aliran modal swasta bernilai US \$ -6,485 juta, terdiri atas penanaman modal langsung US \$ -356 juta dan penanaman modal jangka pendek US $\$-6,450$ juta.

Derasnya aliran modal masuk ke Indonesia disebabkan antara lain oleh semakin meluasnya pasar keuangan dunia hingga ke Indonesia sejak tahun 1990, yang ditunjang 
sistem nilai tukar yang dianut Indonesia ketika itu, dimana nilai tukar rupiah mengalami depresiasi yang relatif stabil.

Pada gambar 1.2 menunjukkan selama periode high capital inflow, yaitu dari tahun 1990 hingga 1996 nilai tukar nominal rupiah terhadap dolar Amerika Serikat mengalami depresiasi yang relatif stabil (rata-rata per tahun sebesar 3,84\%). Pada periode aliran modal keluar (capital outflow) tahun 1997/1998 hingga 1998/1999, nilai tukar rupiah mengalami depresiasi yang sangat tajam (rata-rata per tahun sebesar 124,24\%).

Tabel 1.3

Nilai Tukar Rupiah Terhadap US \$

Tahun $1990-2000$

\begin{tabular}{|c|c|c|c|}
\hline Periode & $\begin{array}{c}\text { Nilai Tukar } \\
\text { (Rp/US\$) }\end{array}$ & Periode & $\begin{array}{c}\text { Nilai Tukar } \\
\text { (Rp/US\$) }\end{array}$ \\
\hline & & 1995 & $\mathbf{2 3 0 8}$ \\
1990 & $\mathbf{1 9 0 1}$ & 1996 & $\mathbf{2 3 8 3}$ \\
1991 & $\mathbf{1 9 9 2}$ & 1997 & $\mathbf{4 6 5 0}$ \\
1992 & $\mathbf{2 0 6 2}$ & 1998 & $\mathbf{8 0 2 5}$ \\
1993 & $\mathbf{2 1 1 0}$ & 1999 & $\mathbf{7 0 8 5}$ \\
1994 & $\mathbf{2 2 0 0}$ & 2000 & $\mathbf{9 5 9 5}$ \\
\hline
\end{tabular}

Sumber : International Financial Statistics.

Selanjutnya pada Gambar 1.3 di bawah ini tampak pergerakan laju inflasi selama periode capital inflow dari tahun 1990/1991 - 1996/1997 relatif stabil di bawah dua digit, yaitu rata-rata per tahun sebesar 8,36 persen, sedangkan pada masa krisis ekonomi melanda Indonesia, yaitu selama periode capital outflow dari tahun 1997/1998 - 1998/1999, laju inflasi meningkat tajam rata-rata per tahun sebesar 55,92 persen.

Berkaitan dengan aliran modal swasta yang masuk cukup deras, apabila bagian terbesar aliran modal masuk dalam bentuk penanaman modal jangka pendek, maka dapat mempengaruhi stabilitas perekonomian Indonesia dari aspek eksternal berupa gejolak nilai tukar rupiah setiap saat. Hal tersebut dapat terjadi ketika berubah menjadi aliran modal keluar, sehingga nilai tukar rupiah mendapat tekanan yang cukup berat.

Perubahan nilai tukar dapat juga disebabkan oleh permintaan dan penawaran mata uang domestik maupun valuta asing melalui kegiatan transaksi ekspor maupun impor. Di samping itu, dalam sistem nilai tukar tetap maupun mengambang terkendali, perubahan nilai tukar akan sangat ditentukan oleh kebijakan nilai tukar yang ditempuh oleh Bank Sentral. 
Krisis ekonomi yang melanda Indonesia diawali oleh aliran modal keluar yang cukup besar. Hal ini merupakan indikasi bahwa aliran modal jangka pendek yang berlebihan, dapat menimbulkan dampak negatif terhadap sektor moneter maupun riil.

Sehubungan dengan pemenuhan kebutuhan modal sebagai salah satu penggerak pembangunan ekonomi (engine of growth), maka selanjutnya melalui penelitian ini akan dilakukan analisis pengaruh aliran modal swasta penanaman modal jangka pendek terhadap indikator ekonomi makro yaitu nilai tukar rupiah dan laju inflasi disamping beberapa faktor lain yang mempengaruhinya.

\section{LANDASAN PEMIKIRAN}

\subsection{Aliran Modal}

Selama periode yang diakhiri dengan Perang Dunia Pertama, arus modal dari Eropa ke kawasan berkembang sangat deras, kebanyakan dalam bentuk kredit biasa. Antara tahun 1870 hingga tahun 1914, Inggris rata-rata menginvestasikan 5\% GNP-nya ke luar negeri. Ada pun Perancis dan Jerman, menginvestasikan masing-masing $2 \%$ dan $3 \% .{ }^{1}$

Di dalam teori-teori pembangunan ekonomi, peranan penting investasi dikemukakan oleh Solow, Harrod-Domar, dan lain-lain. Di dalam model tersebut, tabungan dalam negeri merupakan satu-satunya sumber penbiayaan kebutuhan investasi. Namun demikian di banyak negara sedang berkembang, sumber tersebut sangat terbatas. Oleh karena itu, banyak negara sedang berkembang termasuk Indonesia harus bergantung pada modal asing, baik dalam bentuk pinjaman, bantuan, investasi langsung maupun investasi portfolio.

Berdasarkan teori pilihan portfolio (theory of portfolio choice), faktor-faktor yang mempengaruhi seseorang untuk membeli suatu aset, yakni ${ }^{2}$ :

1. Kekayaan (Wealth), jika kekayaan seseorang semakin meningkat maka ia akan memiliki sumber yang lebih banyak untuk membeli aset-aset.

2. Harapan Hasil (Expected Return), yakni harapan hasil yang didapatkan dengan memegang aset tersebut.

3. Risiko (Risk), yaitu derajat ketidakpastian yang dihubungkan dengan suatu aset relatif terhadap aset-aset lainnya.

4. Likuiditas (Liquidity), yaitu seberapa cepat dan mudah suatu aset diubah dalam bentuk uang tunai (cash)

1 Paul R. Krugman, "Ekonomi Internasional", Universitas Indonesia dan HarperCollin Publisher, edisi ke 2. 1999. 2 Frederic S Mishkin, "The Economics of Money Banking and Financial Market" Harper Collins, 1997 
Sehingga segala tindakan seseorang dalam memegang suatu aset, berhubungan dengan tujuan menanamkan modalnya, akan didasarkan pada keempat faktor tersebut di atas. Sedangkan aset di sini adalah sesuatu yang dimiliki yang merupakan simpanan kekayaan atau nilai. Aset ini bisa berupa uang, obligasi, saham, karya seni, tanah, rumah, peralatan perkebunan, mesin-mesin pabrik dan valuta asing.

\subsection{Penanaman Modal Asing Langsung (Foreign Direct Investment)}

Penanaman modal langsung (foreign direct investment) disebut juga penanaman modal jangka panjang, berarti perusahaan dari negara penanam modal melakukan pengawasan atas aktiva yang diinvestasikan di negara pengimpor modal. Penanaman modal langsung ini dapat dilakukan dengan mendirikan cabang perusahaan di negara pengimpor modal; pendirian perusahaan yang mayoritas sahamnya dimiliki oleh negara penanam modal; pendirian perusahaan di negara pengimpor modal yang semata-mata dibiayai oleh negara asal penanam modal: pendirian perusahaan di negara asal penanam modal untuk secara khusus beroperasi di negara lain; atau menyimpan aktiva tetap di negara lain oleh perusahaan nasional dari negara asal penanam modal.

\subsection{Penanaman Modal Asing Tidak Langsung (Foreign Indirect Investment) ${ }^{3}$}

Penanaman modal asing tidak langsung atau penanaman modal jangka pendek disebut juga investasi portfolio (portfolio investment) merupakan bentuk penanaman modal yang sebagian besar terdiri dari penguasaan atas saham yang dapat dipindahkan (yang dikeluarkan atau dijamin oleh negara pengimpor modal), terhadap saham atau surat utang oleh pemerintah atau warga negara di beberapa negara lain. Penguasaan saham tersebut tidaklah sama dengan hak untuk mengendalikan perusahaan. Para pemegang saham hanya memiliki hak atas deviden.

Adapun motif utama investor asing menanamkan modalnya adalah didorong oleh beberapa alasan, yaitu :

1) melakukan diversifikasi portfolio di antara berbagai pasar dan lokasi,

2) untuk memperoleh keuntungan yang lebih tinggi,

3) menghindari risiko politik (political risks),

4) berspekulasi di pasar valuta asing.

3 Moh. Ikhsan Mahyuddin, Pelarian Modal dari Indonesia: Estimasi dan Masalahnya, Ekonomi dan Keuangan Indonesia, vol. 37, no. 1, 1989 
Di samping itu seringkali dilakukan untuk menghindari pajak yang terlalu besar di suatu negara, atau untuk mendukung kegiatan bisnis di suatu negara yang sarana infrastrukturnya belum memadai.

Untuk mengetahui keadaan aliran modal internasional di suatu negara, dapat dilihat pada catatan neraca pembayaran (balance of payment) negara yang bersangkutan, khususnya dalam transaksi neraca modal (capital account). Bila transaksi neraca modal mengalami surplus, berarti terjadi aliran modal bersih yang masuk (net capital inflow) ke negara tersebut. Dalam hal ini berarti terjadi penjualan aset finansial ke luar negeri yang lebih besar dari pada pembelian aset finansial dari luar negeri. Aliran modal masuk ini cenderung meningkatkan aliran cadangan internasional, sehingga dapat memperbaiki kinerja neraca pembayaran yang dibarengi dengan terapresiasinya nilai tukar.

Sebaliknya, transaksi modal yang defisit menunjukkan terjadinya aliran modal bersih ke luar negeri, atau negara tersebut secara keseluruhan membeli aset finansial luar negeri. Bila hal ini terjadi, berarti aliran cadangan internasional ke luar negeri meningkat, pada gilirannya akan memperburuk neraca pembayaran yang disertai dengan terdepresiasinya nilai tukar.

Selama periode meningkatnya aliran modal masuk (capital inflow) telah mengakibatkan apresiasi nilai tukar riil. Hal ini merupakan dampak yang terkandung di dalam aliran modal masuk yang terlampau deras, terutama jika aliran modal didominasi oleh investasi asing berupa investasi portfolio atau investasi berjangka pendek. Secara teoritis, suatu perekonomian terbuka dengan arus lalulintas modal yang bebas, nilai tukar mata uangnya cenderung mengalami apresiasi karena adanya capital inflow yang didukung oleh perbedaan suku bunga (interest differential) yang positif. Hal serupa pun akan terjadi jika surplus neraca pembayaran yang berkelanjutan sebagai hasil dari aliran dana masuk ke dalam negeri menjadikan posisi nilai tukar rupiah cenderung menguat. Selanjutnya, di tengah krisis, faktor risiko, baik politik, keuangan maupun ekonomi (faktor fundamental ekonomi) merupakan pendorong utama terjadinya depresiasi nilai tukar yang tidak terkendali.

Dalam kaitan pengaruh aliran modal swasta penanaman modal jangka pendek terhadap perubahan nilai tukar rupiah, dapat dijelaskan sebagai berikut: dengan adanya aliran modal masuk, berarti telah terjadi pengalihan mata uang asing ke mata uang rupiah. Hal ini berarti permintaan terhadap mata uang rupiah mengalami peningkatan, sehingga nilai tukar rupiah mengalami apresiasi. Sebaliknya bila terjadi aliran modal keluar, maka permintaan terhadap mata uang asing meningkat, dengan demikian nilai tukar rupiah mengalami depresiasi. 
Secara khusus faktor-faktor yang mempengaruhi aliran modal swasta jangka pendek, dapat dijelaskan berdasarkan teori paritas suku bunga (interest parity theory) dan pendekatan moneter dalam penentuan nilai tukar (the monetary approach to exchange rate determination) serta teori portfolio (the portfolio theory). ${ }^{4}$

\subsubsection{Teori paritas suku bunga}

Teori paritas suku bunga juga menjelaskan bahwa bila perbedaan suku bunga tabungan domestik dan suku bunga luar negeri sama dengan tingkat swap, yaitu perbedaan antara kurs di masa mendatang (forward exchange rate) dan nilai tukar spot relatif terhadap nilai tukar spot, maka kondisi demikian menunjukkan di mana masyarakat tidak akan memperoleh keuntungan apapun bila menginvestasikan dananya di luar negeri. Secara matematis teori tersebut adalah:

$$
i-i^{*}=\frac{f-e}{e}
$$

dimana:

$\mathrm{i}$ = suku bunga tabungan domestik (dalam mata uang domestik)

$\mathrm{i}^{*}=$ suku bunga tabungan luar negeri (dalam mata uang asing)

$\mathrm{f}=$ nilai tukar di masa mendatang

$\mathrm{e}=$ nilai tukar spot.

Persamaan (2.1.) menunjukkan pada bagian kiri merupakan keuntungan atau kerugian yang diperoleh bila menyimpan aset dalam mata uang domestik. Jika $\mathrm{i}>\mathrm{i}^{*}$, berarti ada keuntungan yang akan diperoleh bila menyimpan aset domestik, demikian pula sebaliknya. Bagian kanan menunjukkan adanya resiko yang akan ditanggung ataupun keuntungan yang akan diperoleh bila terjadi perubahan nilai tukar. Selanjutnya jika $\left(\mathrm{i}>\mathrm{i}^{*}\right)>(\mathrm{f}>\mathrm{e})$, maka akan lebih menguntungkan bila menyimpan aset domestik, demikian pula sebaliknya.

Berdasarkan persamaan diatas maka rate of return Rupiah atas simpanan dollar kurang lebih sama dengan suku bunga dollar AS ditambah dengan tingkat depresiasi rupiah terhadap dollar AS. Jika tingkat bunga domestik di atas tingkat bunga luar negeri, maka terdapat positive appreciation dalam mata uang luar negeri, yang harus diimbangi dengan penurunan tingkat bunga luar negeri.

\subsubsection{Pendekatan Moneter}

Pendekatan moneter dimulai dengan dalil bahwa permintaan uang berhubungan

4 Moh. Ikhsan Mahyuddin, Pelarian Modal dari Indonesia: Estimasi dan Masalahnya, Ekonomi dan Keuangan Indonesia, vol. 37, no. 1, 1989 
positif terhadap tingkat pendapatan nasional nominal dan stabil pada jangka panjang. ${ }^{5}$

Persamaan permintaan uang dapat dituliskan sebagai berikut:

$\mathrm{Md}=k \mathrm{PY}$

Dimana $\quad$ Md = jumlah uang nominal yang diminta

$k=$ rasio hasrat pemegangan uang nominal terhadap pendapatan nasional

$\mathrm{P}$ = tingkat harga domestik

$\mathrm{Y}=$ output riil

Pada persamaan (2.2), PY merupakan pendapatan nasional nominal atau output (GDP) yang diasumsikan menuju kepada full employment pada jangka panjang.

Sedangkan penentuan nilai tukar antara rupiah dan dollar berdasarkan pendekatan moneter dimulai dengan fungsi permintaan uang nominal dari Indonesia $\left(\mathrm{Md}_{\mathrm{INA}}\right)$ dan Amerika Serikat $\left(\mathrm{Md}_{\mathrm{US}}\right)$

$$
\begin{aligned}
& \mathrm{Md}_{\mathrm{INA}}=k \mathrm{P}_{\mathrm{INA}} \mathrm{Y} \text { dan } \mathrm{Md}_{\mathrm{US}}=k \mathrm{P}_{\mathrm{US}} \mathrm{Y} \\
& \text { Dimana } \mathrm{P}_{\mathrm{INA}}=\text { tingkat harga di Indonesia } \\
& \mathrm{P}_{\mathrm{US}}=\text { tingkat harga di Amerika Serikat }
\end{aligned}
$$

Dalam keseimbangan, jumlah uang yang diminta sama dengan jumlah uang yang ditawarkan. Jadi $\mathrm{Md}_{\mathrm{INA}}=\mathrm{Ms}_{\mathrm{INA}}$ dan $\mathrm{Md}_{\mathrm{US}}=\mathrm{Ms}_{\mathrm{US}}$. Dengan mensubstitusikan $\mathrm{Ms}_{\mathrm{INA}}$ untuk $\mathrm{Md}_{\mathrm{INA}}$ dan $\mathrm{Ms}_{\mathrm{US}}$ untuk $\mathrm{Md}_{\mathrm{Us}}$ maka didapatkan fungsi sebagai berikut:

$$
\frac{M s_{U S}}{M s_{I N A}}=\frac{k_{U S} P_{U S} Y_{U S}}{k_{I N A} P_{I N A} Y_{I N A}}
$$

Dengan membagi kedua sisi dengan $\frac{P_{U S}}{P_{I N A}}$ dan $\frac{M s_{U S}}{M s_{I N A}}$ kita dapatkan:

$$
\frac{P_{I N A}}{P_{U S}}=\frac{M s_{I N A} k_{U S} Y_{U S}}{M s_{U S} k_{I N A} Y_{I N A}}
$$

Dengan $E_{R p / \$}=\frac{P_{I N A}}{P_{U S}}$ pada teori PPP, maka diperoleh:

5 Dominick Salvatore, "International Economics", John Wiley \& Sons, seventh edition. 


$$
E_{R p / \$}=\frac{M s_{I N A} k_{U S} Y_{U S}}{M s_{U S} k_{I N A} Y_{I N A}}
$$

Dengan mengasumsikan $k_{u s}$ dan $Y_{u s}$ di Amerika dan $k_{I N A}$ dan $Y_{I N A}$ di Indonesia diasumsikan tetap (konstan), maka $E_{r p / s}$ adalah tetap selama $M s_{I N A}$ dan $M s_{u s}$ tidak berubah. Jadi $E_{r p / s}$ berubah secara proporsional terhadap perubahan $M s_{I N A}$ dan kebalikan proporsional $M s_{\text {us. }}$

\subsection{Nilai Tukar}

Nilai tukar suatu negara menunjukkan harga mata uang negara tersebut terhadap mata uang negara lain. Nilai tukar mata uang suatu negara mengalami apresiasi ketika nilai mata uangnya meningkat relatif terhadap nilai mata uang negara lain.

Perubahan nilai tukar dipengaruhi oleh beberapa faktor yang mempengaruhinya dalam jangka pendek dan jangka panjang. Faktor-faktor yang mempengaruhi dalam jangka pendek adalah harga asset dan perbedaan tingkat bunga. Sedangkan faktor yang mempengaruhi nilai tukar dalam jangka panjang yaitu harga relatif, tariff dan kuota, preferensi terhadap barang domestik dibandingkan terhadap barang luar negeri serta produktivitas.

Ada tiga teori yang dapat menjelaskan terjadinya depresiasi ataukah apresiasi mata uang suatu negara, yaitu:

1) Pelarian modal internasional, dimana para investor mengalihkan dana mereka ke luar negeri, sehingga nilai tukar mata uang domestik melemah.

2) Tingginya defisit anggaran pemerintah, sehingga pemerintah mencari pinjaman dalam mata uang asing, yang berakibat suku bunga meningkat. Hal ini dapat menarik masuknya modal asing yang menyebabkan mata uang domestik menguat atau terapresiasi.

3) Meningkatnya investasi nyata yang bebas dalam bentuk bangunan dan peralatan baru, yang membantu menaikkan suku bunga dan menarik dana-dana asing menjadi mata uang domestik, sehingga mata uang domestik menguat.

\subsection{Inflasi}

Inflasi adalah keadaan dimana terjadi peningkatan harga umum secara terus-menerus. Inflasi merupakan gejala ekonomi yang sangat menarik untuk diperhatikan karena setiap kali ada gejolak sosial, politik, atau ekonomi di dalam maupun di luar negeri, masyarakat selalu mengaitkannya dengan masalah inflasi. 
Inflasi juga bisa menunjukkan kerentanan perekonomian suatu negara sehingga hal ini sangat berpengaruh terhadap kepercayaan penanaman modal, terutama modal asing akan prospek pendapatan yang akan diperolehnya di negara tersebut. Inflasi bisa terjadi karena adanya kelebihan permintaan terhadap barang dan jasa di sektor riil atau karena adanya kelebihan jumlah uang yang beredar.

Sehingga masyarakat akan melakukan pengeluaran (spending) lebih besar, padahal output riil sudah mencapai keadaan full employment (menurut golongan monetaris). Adapun faktor-faktor yang memungkinkan terjadinya inflasi bisa dilihat melalui teori kuantitas uang sederhana dan analisis ortodoks tentang inflasi (Demand-Pull dan Supply-Side serta Demand-Supply Theories of Inflation).

\subsection{Ekspor, Impor dan Defisit Neraca Jasa}

Selain itu, faktor lain yang dapat menyebabkan perubahan nilai tukar rupiah adalah besarnya nilai devisa yang diperoleh dari hasil ekspor barang dan besarnya kebutuhan dana dalam bentuk valuta asing untuk membiayai impor barang dan defisit neraca jasa.

Dalam kenyataan sehari-hari, perdagangan luar negeri suatu negara sangat jarang seimbang. Selisih antara ekspor barang dan jasa serta impor barang dan jasa disebut sebagai neraca transaksi berjalan (current account balance) atau sering disingkat transaksi berjalan (current account, dengan simbol CA). Secara matematis, keadaan tersebut dapat dirumuskan sebagai berikut:

$\mathrm{CA}=\mathrm{EX}-\mathrm{IM}$

Apabila impor suatu negara melebihi ekspornya, maka negara itu kita sebut mengalami defisit transaksi berjalan (current account defisit). Suatu negara disebut mengalami surplus transaksi berjalan (current account surplus) bila ekspornya lebih besar daripada impornya.

Transaksi berjalan juga penting karena ia mengukur arah dan besarnya pinjaman internasional. Bila suatu negara mengimpor lebih banyak daripada mengekspor, maka ia membeli dari pihak-pihak luar negeri lebih banyak daripada menjual kepada mereka. Akibatnya negara tersebut mengalami defisit transaksi berjalan yang harus ditutup dengan jalan melakukan pinjaman luar negeri jika pendapatan ekspornya telah habis dipakai. Alternatif lainnya ialah dengan cara menggunakan kekayaan luar negerinya untuk menutupi defisit transaksi berjalannya atau dengan cara mengeluarkan cadangan devisa negara yang mengalami defisit.

Dengan demikian berkurangnya cadangan internasional suatu negara yang mengalami defisit transaksi berjalan akan mengakibatkan mata uang negara tersebut mengalami 
depresiasi. Hal yang sebaliknya akan terjadi ketika suatu negara mengalami surplus dalam transaksi berjalannya, maka akan menambah posisi bersih kekayaan luar negeri negara tersebut atau cadangan internasional negara yang mengalami surplus transaksi berjalan akan bertambah dan mengakibatkan mata uang negara tersebut mengalami apresiasi.

Secara sederhana meningkatnya permintaan ekspor barang Indonesia dapat meningkatkan permintaan terhadap rupiah sehingga rupiah akan mengalami apresiasi. Di sisi lain, meningkatnya permintaan valuta asing melalui peningkatan nilai impor barang ditambah defisit neraca jasa, dapat mengakibatkan nilai tukar rupiah melemah.

\section{GAMBAR 1.1 KERANGKA PEMIKIRAN PENGARUH ALIRAN MODAL SWASTA JANGKA PENDEK TERHADAP PERUBAHAN NILAI TUKAR RUPIAH DAN LAJU INFLASI DI INDONESIA PERIODE 1990.I - 2000.IV}

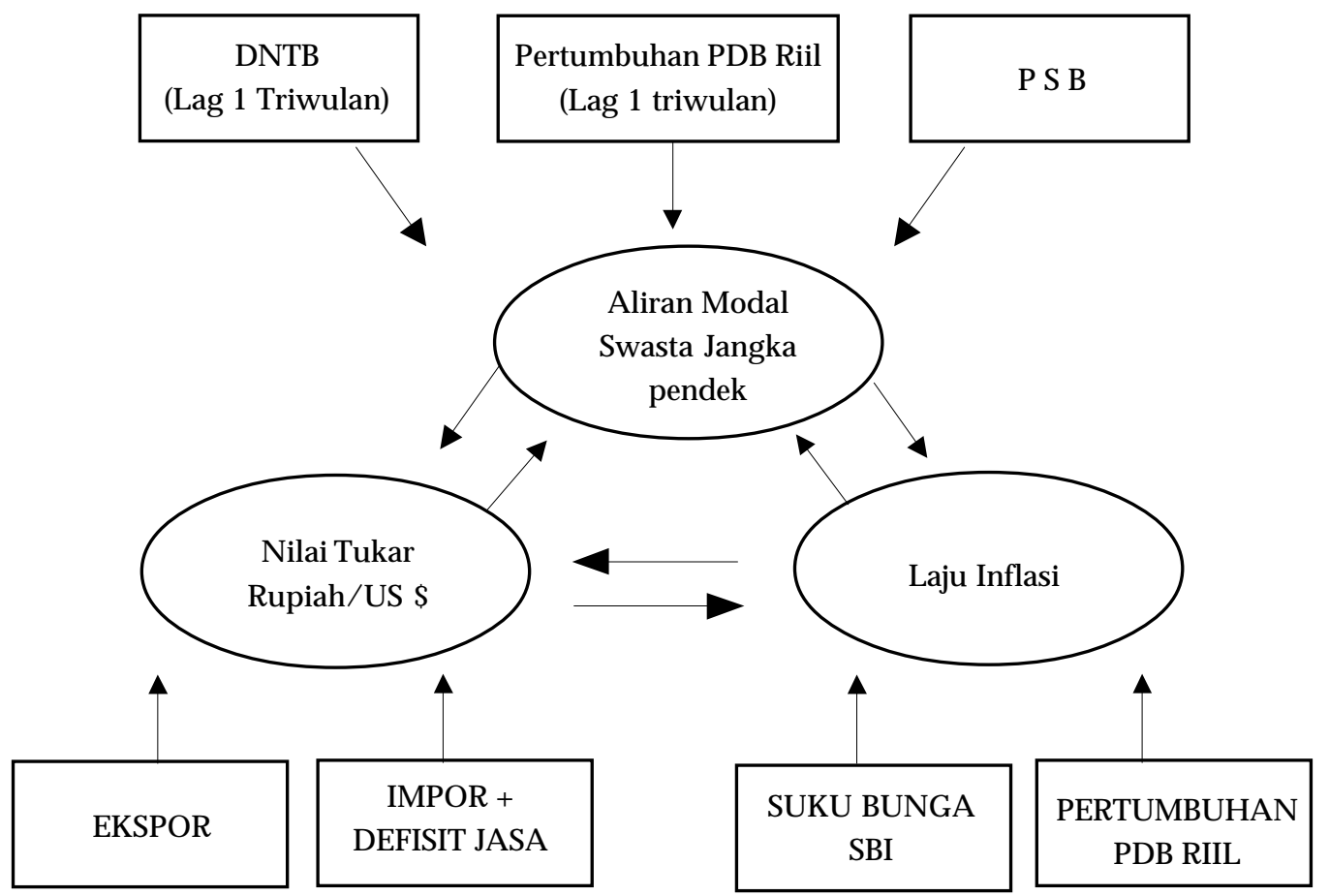

\section{MODEL EKONOMETRIKA DAN METODE ESTIMASI}

Metode yang digunakan untuk menjawab permasalahan penelitian ini adalah dengan menggunakan pendekatan model ekonometrika yaitu analisis regresi linier berganda dua tahap (Two Stage Least Squares). 
3.1 Model ekonometrik untuk analisis aliran modal swasta adalah: ${ }^{6}$

AMS $=a_{10}+a_{11} \operatorname{LnNT}_{t}+a_{12} \operatorname{LnIHK}_{t}+a_{13} \operatorname{LnPDB}_{t-1}+a_{14} \operatorname{DNTB}_{t-1}+a_{15}$ PSB $_{t}+e^{*}$

3.2 Model ekonometrik untuk analisis pengaruh aliran modal swasta terhadap perubahan nilai tukar adalah: ${ }^{7}$

$\mathrm{LnNT}_{\mathrm{t}}=\mathrm{b}_{20}+\mathrm{b}_{21} \mathrm{AMS}_{\mathrm{t}}+\mathrm{b}_{22} \mathrm{LnIHK}_{\mathrm{t}}+\mathrm{b}_{23} \mathrm{EKSP}_{\mathrm{t}}+\mathrm{b}_{24} \mathrm{IMJS}_{\mathrm{t}}+\mathrm{e}^{*}{ }_{2 \mathrm{t}}$

3.3 Model ekonometrik untuk analisis pengaruh aliran modal swasta terhadap laju inflasi adalah: ${ }^{8}$

LnIHK $_{t}=g_{30}+g_{31}$ AMS $_{t}+g_{32} \operatorname{LnNT}_{t}{ }_{t}+g_{33} \operatorname{LnPDB}_{t}+g_{34} \mathrm{SBI}_{t}+e^{*}$

Diharapkan: $\mathrm{a}_{11}<0, \mathrm{a}_{12}<0, \mathrm{a}_{13}>0, \mathrm{a}_{14}>0, \mathrm{a}_{15}>0, \mathrm{~b}_{21}<0, \mathrm{~b}_{22}>0, \mathrm{~b}_{23}<0, \mathrm{~b}_{24}>0, \mathrm{~g}_{31}>0$, $g_{32}>0, g_{33}<0$ dan $g_{34}<0$

Keterangan:

AMS $_{t} \quad$ : Nilai aliran modal swasta penanaman modal jangka pendek triwulanan

$\mathrm{LnNT}_{\mathrm{t}} \quad$ : Perubahan nilai tukar rupiah per US \$ triwulanan

LnIHK $_{t} \quad$ : Laju inflasi triwulanan

LnPDB $_{\mathrm{t}-1} \quad$ : Pertumbuhan produksi domestik bruto riil lag satu triwulanan

DNTB $_{t-1} \quad$ : Defisit transaksi berjalan lag satu triwulanan

$\mathrm{PSB}_{\mathrm{t}} \quad$ : Perbedaan suku bunga domestik dan luar negeri triwulanan

$\mathrm{e}^{*}{ }_{1 \mathrm{t}} \quad$ : Error term persamaan (3.1)

EKSP $_{\mathrm{t}} \quad$ : Nilai ekspor barang triwulanan

IMJS $_{\mathrm{t}} \quad$ : Nilai impor dan defisit neraca jasa triwulanan

$\mathrm{e}^{*} \quad$ : Error term persamaan (3.2)

$\mathrm{LnPDB}_{\mathrm{t}} \quad:$ Pertumbuhan produksi domestik bruto riil triwulanan

SBI $_{t} \quad$ : Tingkat suku bunga sertifikat Bank Indonesia triwulanan

$\mathrm{e}_{3 \mathrm{t}}^{*} \quad$ : Error term persamaan (3.3)

Apabila dihubungkan, persamaan-persamaan diatas akan membentuk suatu sistem persamaan simultan dengan tiga persamaan dan tiga variabel endogen. Setelah dilakukan pengujian rank dan order menunjukkan persamaan tersebut Overidentified.

6 Muh. Ilham, Keterkaitan Aliran Modal Swasta Non Penanaman Modal Langsung Terhadap Perubahan Nilai tukar dan Laju Inflasi di Indonesia, Tesis Program Pasca Sarjana, Universitas Padjadjaran.

7 Ibid hal, 74 modifikasi

8 Ibid, hal 78 


\section{SUMBER DATA DAN HASIL ESTIMASI}

Data yang digunakan dalam penulisan skripsi ini merupakan data kuantitatif tahunan pada periode 1990:I sampai dengan 2000:IV. Data tersebut diperoleh dari berbagai sumber diantaranya :

1. International Financial Statistic, IMF.

2. Laporan Bank Indonesia, BI.

3. Statistik Ekonomi dan Keuangan Indonesia, BI.

4. Indikator Perekonomian Indonesia, BPS.

5. Data lain yang bersumber dari referensi studi kepustakaan melalui makalah, jurnal, artikel dan bahan lain dari Perpustakaan Extension FE-UNPAD, Perpustakaan pasca sarjana ekonomi UNPAD, Perpustakaan Bank Indonesia dan BPS Bandung.

6. Bahan-bahan lain yang sekiranya dibutuhkan oleh pihak penulis.

Hasil estimasi yang dilakukan terhadap model ekonometrika yang digunakan dirangkum dalam tabel berikut :

\begin{tabular}{|c|c|c|c|c|c|c|}
\hline Persamaan & Variabel & Koefisien & SE & t-stat & Keterangan & $\mathrm{R}^{2}, \mathrm{DW}, \mathrm{F}$ \\
\hline $\begin{array}{c}\text { Aliran Modal } \\
\text { Swasta } \\
\text { Jangka } \\
\text { Pendek } \\
(3.1)\end{array}$ & $\begin{array}{l}\text { LnNT } \\
\text { LnIHK } \\
\text { LnPDB(-1) } \\
\text { DNTB(-1) } \\
\text { PSB } \\
\text { Constant }\end{array}$ & $\begin{array}{l}-4.32 \mathrm{E}+09 \\
4.21 \mathrm{E}+09 \\
-2.78 \mathrm{E}+09 \\
0.072860 \\
-5753290 \\
1.02 \mathrm{E}+11\end{array}$ & $\begin{array}{l}2.03 \mathrm{E}+09 \\
4.76 \mathrm{E}+09 \\
5.29 \mathrm{E}+09 \\
0.770839 \\
40365467 \\
1.53 \mathrm{E}+11\end{array}$ & $\begin{array}{c}-2.133638 \\
0.884052 \\
-0.525050 \\
0.094520 \\
-0.142530 \\
0.665136\end{array}$ & $\begin{array}{c}\text { Signifikan* } \\
\text { Tidak Signifikan } \\
\text { Tidak Signifikan } \\
\text { Tidak Signifikan } \\
\text { Tidak Signifikan } \\
\text { Tidak Signifikan }\end{array}$ & $\begin{array}{c}\mathrm{R}^{2}=0.548796 \\
\mathrm{Adj}^{2}=0.486128 \\
\mathrm{D} \text { test }=1.946067 \\
\mathrm{~F} \text { test }=7.016820\end{array}$ \\
\hline $\begin{array}{c}\text { Perubahan } \\
\text { Nilai Tukar } \\
\text { Rupiah } \\
\text { (3.2) } \\
\text { Constant }\end{array}$ & $\begin{array}{l}\text { LnIHK } \\
\text { EKSP } \\
\text { IMJS } \\
\text { AMS } \\
2.873465\end{array}$ & $\begin{array}{l}1.014209 \\
-8.51 \mathrm{E}-11 \\
9.46 \mathrm{E}-11 \\
-7.50 \mathrm{E}-11 \\
1.009507\end{array}$ & $\begin{array}{l}0.226504 \\
5.56 \mathrm{E}-11 \\
4.23 \mathrm{E}-11 \\
3.50 \mathrm{E}-11 \\
2.846403\end{array}$ & $\begin{array}{c}4.477658 \\
-1.529727 \\
2.236988 \\
-2.144525 \\
\text { Signifikan* }\end{array}$ & $\begin{array}{l}\text { Signifikan* } \\
\text { Signifikan*** } \\
\text { Signifikan* } \\
\text { Signifikan* }\end{array}$ & $\begin{aligned} \mathrm{R}^{2}= & 0.934610 \\
\text { Adj } \mathrm{R}^{2} & =0.927727 \\
\mathrm{D} \text { test } & =1.684480 \\
\mathrm{~F} \text { test } & =128.5669\end{aligned}$ \\
\hline $\begin{array}{c}\text { Laju Inflasi } \\
(3.3)\end{array}$ & $\begin{array}{l}\text { AMS } \\
\text { LnNT } \\
\text { LnPDB } \\
\text { SBI } \\
\text { Constant }\end{array}$ & $\begin{array}{l}4.03 \mathrm{E}-11 \\
0.722001 \\
0.415577 \\
-0.004793 \\
-13.81053\end{array}$ & $\begin{array}{l}2.25 \mathrm{E}-11 \\
0.055641 \\
0.108838 \\
0.002110 \\
3.374263\end{array}$ & $\begin{array}{l}1.794861 \\
12.97601 \\
3.818295 \\
-2.271661 \\
-4.092902\end{array}$ & $\begin{array}{l}\text { Signifikan** } \\
\text { Signifikan* } \\
\text { Signifikan* } \\
\text { Signifikan* } \\
\text { Signifikan* }\end{array}$ & $\begin{array}{l}R^{2}=0.955212 \\
\text { Adj } R^{2}=0.950497 \\
D \text { test }=1.562473 \\
F \text { test }=200.8799\end{array}$ \\
\hline
\end{tabular}

Keterangan: $* * *$ signifikan pada tingkat kepercayaan 95 persen

** signifikan pada tingkat kepercayaan 90 persen

signifikan pada tingkat kepercayaan 85 persen

\section{ANALISIS STATISTIK DARI MODEL DAN ANALISIS EKONOMI}

\subsection{Analisis Statistik dari Model dan Analisis Ekonomi Model (3.1)}

Analisis Statistik:

Pada Persamaan (3.1) menunjukkan nilai t-statistik perubahan nilai tukar rupiah 
( LnNT $_{\mathbf{t}}$ reduced form) sebesar -2.133638 berpengaruh signifikan terhadap aliran modal swasta jangka pendek (AMS) pada taraf 5 persen. Laju inflasi ( LnIHK $_{\mathbf{t}}$ reduced form) tidak berpengaruh signifikan terhadap AMS ${ }_{\mathrm{t}}$ pada taraf 10 persen dengan nilai t-statistik sebesar 0.884052. Nilai t-statistik pertumbuhan produk domestik bruto riil atau LnPDB(-1) sebesar -0.525050, yang menunjukkan bahwa pengaruh pertumbuhan produk domestik bruto riil tidak signifikan terhadap AMS pada taraf 10 persen

Defisit neraca transaksi berjalan triwulan sebelumnya (DNTB(-1) $)_{t}$ tidak berpengaruh signifikan terhadap aliran modal swasta jangka pendek (AMS $)_{t}$ ) pada taraf 10 persen di mana nilai t-statistik DNTB(-1) sebesar 0.094520. sedangkan yang terakhir ialah perbedaan suku bunga domestik dengan suku bunga luar negeri $\left(\mathrm{PSB}_{\mathrm{t}}\right)$, memiliki pengaruh yang tidak signifikan terhadap aliran modal swasta jangka pendek $\left(\mathrm{AMS}_{\mathrm{t}}\right)$ pada taraf 10 persen. Sedangkan pengujian keseluruhan dari model (uji F) menunjukkan seluruh persamaan signifikan dalam menjelaskan variabel terikatnya. Dalam pengujian autokorelasi kesimpulan umum yang dapat diambil adalah tidak ada gejala autokorelasi pada model yang digunakan. Sehingga secara umum model yang digunakan sudah memenuhi kriteria BLUE.

\section{Analisis Ekonomi:}

Dari estimasi Persamaan (3.1), diketahui hanya satu variabel dari seluruh variabel bebas dalam persamaan aliran modal swasta jangka pendek terhadap variabel tak bebasnya yang memiliki pengaruh signifikan. Variabel tersebut adalah perubahan nilai tukar nominal rupiah/US \$. Nilai koefisien dari perubahan nilai tukar nominal rupiah/US \$ tersebut adalah sebesar $-4,32 \mathrm{E}+09$. Hal ini menunjukkan bahwa ketika terjadi depresiasi nilai tukar nominal rupiah/US \$ sebesar 1 persen, maka aliran modal swasta jangka pendek akan berkurang sebesar US $\$ 4320$ juta, jika hal lain tetap. Pengaruh negatif ini berkaitan dengan nilai riil dari keuntungan yang akan diperoleh para investor dalam menanamkan modalnya, yaitu ketika depresiasi meningkat tajam, maka nilai riil keuntungan yang diperoleh investor atas dana-dana mereka akan berkurang. Sedangkan variabel-variabel lainnya yang merupakan variabel laju inflasi, pertumbuhan produk domestik bruto riil triwulan sebelumnya, defisit neraca transaksi berjalan triwulan sebelumnya dan perbedaan suku bunga domestik dengan luar negeri tidak mempengaruhi aliran modal swasta jangka pendek secara signifikan. Hal ini mengindikasikan bahwa aliran modal swasta jangka pendek dari dan ke dalam negeri Indonesia lebih diakibatkan oleh faktor lain, seperti faktor ketidakpastian politik dan situasi sosial. Sehingga dalam keadaan ketidakpastian ini, Indonesia sering dijadikan sebagai "pasar" spekulasi oleh para spekulan, terutama para spekulan valuta asing. Sehingga pada akhirnya hanya perubahan nilai tukar nominal rupiah/US \$ sajalah 
yang hanya mempengaruhi aliran modal swasta jangka pendek di Indonesia pada periode penelitian ini.

\subsection{Analisis Statistik dari Model dan Analisis Ekonomi Model (3.2)}

Analisis Statistik:

Pada Persamaan (3.2) menunjukkan nilai t-statistik aliran modal swasta jangka pendek

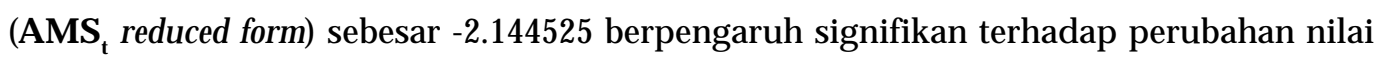
tukar rupiah/US \$ ( LnNT $_{\mathbf{t}}$ ) pada taraf 5 persen. Laju inflasi ( LnIHK $_{\mathbf{t}}$ reduced form) berpengaruh signifikan terhadap LnNT $_{\mathrm{t}}$ pada taraf 1 persen dengan nilai t-statistik sebesar 4.477658 . Nilai t-statistik ekspor barang (EKSP) ) sebesar-1.529727, yang menunjukkan bahwa pengaruh EKSP $_{t}$ tidak signifikan terhadap LnNT $_{t}$ pada taraf 10 persen.

Impor barang ditambah defisit jasa (IMJS) terhadap $\mathrm{LnNT}_{\mathrm{t}}$ yang signifikan pada taraf 5 persen di mana nilai t-statistik $\mathrm{IMJS}_{\mathrm{t}}$ sebesar 2.236988. Sedangkan pengujian keseluruhan dari model (uji F) menunjukkan seluruh persamaan signifikan dalam menjelaskan variabel terikatnya. Sedangkan sehubungan dengan pengujian autokorelasi pada persamaan ini yang tidak meyakinkan, maka selanjutnya dilakukan pengujian loncatan (Run test). Berdasarkan hasil Run test, diperoleh nilai $\mathrm{K}$ (loncatan) sebanyak 13. Dengan asumsi $\mathrm{H}_{0}=$ tidak terdapat autokorelasi, pada tingkat kepercayaan 95 persen ternyata K berada di antara interval atau $\mathrm{H}_{0}$ diterima (lihat lampiran), sehingga dapat disimpulkan bahwa Persamaan (3.2) tidak mengandung serial korelasi.

\section{Analisis Ekonomi:}

Dari hasil estimasi Persamaan (3.2) diketahui hubungan antara aliran modal swasta jangka pendek menunjukkan arah yang negatif terhadap perubahan nilai tukar nominal rupiah/US \$. Nilai koefisien tersebut adalah sebesar -7.50E-11. Hal ini berarti jika hal lain tetap (ceteris paribus), penurunan aliran modal swasta jangka pendek sebesar US \$ 10 milyar, maka nilai tukar rupiah akan mengalami depresiasi terhadap US \$ sebesar 0,75 persen. Hal ini menjelaskan bahwa ketika terjadi pelarian modal dalam bentuk modal swasta jangka pendek ke luar negeri akan menyebabkan terdepresiasinya nilai tukar nominal rupiah/US \$. Pengaruh negatif aliran modal swasta jangka pendek terhadap perubahan nilai tukar rupiah terjadi karena aliran modal keluar menunjukkan menurunnya penawaran mata uang dollar USA, sebaliknya dengan mata uang rupiah mengalami penurunan dalam permintaan. Sesuai dengan kondisi tersebut, penawaran dollar yang menurun mengakibatkan naiknya harga dollar, sebaliknya dengan permintaan rupiah yang menurun akan mengakibatkan turunnya harga rupiah, sehingga pada akhirnya terjadi depresiasi nilai tukar nominal 
rupiah/US \$. Hal ini sesuai dengan penelitian yang telah dilakukan oleh Yati Kurniati, di mana aliran modal memiliki pengaruh negatif dan signifikan terhadap perubahan nilai tukar. Sehingga Yati berpendapat perlunya capital control untuk menjaga volatilitas nilai tukar rupiah yang selanjutnya bisa meredam ketidakstabilan keuangan.

Selanjutnya laju inflasi berpengaruh positif terhadap perubahan nilai tukar rupiah/ US \$ dengan nilai koefisien sebesar 1,01, yaitu bila laju inflasi meningkat 1 persen (ceteris paribus), maka nilai tukar rupiah akan terdepresiasi terhadap US \$ sebesar 1,01 persen. Menurut teori purchasing power parity telah dikemukakan bahwa laju inflasi domestik yang lebih besar dibanding laju inflasi luar negeri akan menyebabkan melemahnya nilai tukar mata uang domestik. Sehingga ketika terjadi peningkatan harga barang-barang dan jasajasa domestik relatif terhadap harga barang-barang dan jasa-jasa luar negeri maka yang terjadi adalah rasio dari harga barang-barang dan jasa-jasa domestik terhadap harga barangbarang dan jasa-jasa luar negeri menjadi meningkat. Sesuai dengan teori tersebut hal yang akan terjadi adalah terdepresiasinya nilai tukar dalam hal ini rupiah/US \$. Hal ini sesuai dengan penelitian yang telah dilakukan oleh Frankel yang menggunakan pendekatan PPP untuk mengetahui pengaruh inflasi terhadap nilai tukar. Dalam penelitiannya terbukti bahwa inflasi mempengaruhi nilai tukar secara positif tetapi dalam kurun waktu yang cukup panjang.

Pengaruh ekspor barang terhadap perubahan nilai tukar rupiah/US \$ menunjukkan arah yang negatif dengan nilai koefisien sebesar -8.51E-11. Hal ini mengisyaratkan bahwa jika nilai ekspor barang meningkat sebesar US \$ 10 milyar (ceteris paribus), maka nilai tukar rupiah akan mengalami apresiasi terhadap US \$ sebesar 0,85 persen. Hal ini menjelaskan bahwa apabila nilai ekspor keluar negeri semakin besar, akan mengakibatkan terapresiasinya nilai tukar nominal rupiah/US \$. Asumsinya ketika penerimaan ekspor yang diterima dalam bentuk mata uang dollar Amerika meningkat, maka hal ini akan meningkatkan perolehan cadangan devisa. Peningkatan perolehan cadangan devisa ini akan meningkatkan penawaran US \$. Sesuai dengan teori ekonomi yang telah dijelaskan pada bab tinjauan pustaka, ketika terjadi peningkatan penawaran US \$ relatif terhadap penawaran rupiah, maka yang terjadi adalah terapresiasinya rupiah terhadap US \$. Tetapi pengaruh ekspor yang tidak signifikan ini lebih diakibatkan oleh kuatnya permintaan akan barang-barang impor yang ditunjukkan oleh nilai neraca jasa yang selalu mengalami defisit, sehingga kemampuan ekspor untuk memperkuat nilai tukar rupiah tidak dapat diandalkan.

Sedangkan pengaruh nilai impor ditambah defisit jasa terhadap perubahan nilai tukar rupiah/US \$ memiliki arah yang positif dengan nilai koefisien sebesar 9.46E-11. Pengaruh tersebut menjelaskan jika nilai impor barang ditambah defisit neraca jasa meningkat sebesar US \$10 milyar (ceteris paribus), maka mata uang rupiah akan terdepresiasi terhadap 
US \$ sebesar 0,95 persen. Hal ini menjelaskan bahwa semakin besar nilai impor ditambah defisit neraca jasa, maka nilai tukar rupiah akan terus terdepresiasi terhadap dollar Amerika. Dengan membandingkan nilai koefisien impor ditambah defisit jasa sebesar 0,95 dengan nilai koefisien ekspor sebesar 0,85, dapat diambil suatu kesimpulan bahwa impor ditambah defisit jasa lebih besar pengaruhnya terhadap perubahan nilai tukar rupiah/US \$. Dengan melihat kondisi current account Indonesia yang selalu mengalami defisit, di mana nilai impor barang-barang dan jasa-jasa yang lebih besar daripada nilai ekspor barang-barang dan jasa-jasanya, hal ini jelas akan memperburuk kondisi nilai tukar rupiah/US \$. Kejadian ini lebih disebabkan karena kebanyakan bahan baku yang digunakan dalam proses produksi di Indonesia selalu bergantung pada barang impor. Sedangkan defisit neraca jasa terjadi karena Indonesia lebih banyak membayar tenaga kerja asing profesional. Walaupun Indonesia cukup banyak "mengekspor" tenaga kerja ke luar negeri, tetapi tingkat keterampilan dari tenaga kerja tersebut rendah dibandingkan dengan tenaga kerja asing yang dipekerjakan di Indonesia. Sehingga yang terjadi adalah Indonesia selalu mengalami defisit neraca jasa.

Sedangkan dalam hal ekspor, Indonesia tidak bisa meningkatkan kapasitas produk ekspornya di samping produk yang tidak bisa bersaing di luar negeri, hambatan perdangangan yang secara langsung mempengaruhi nilai ekspor seperti adanya hambatan tariff dan quota perdagangan juga dianggap sebagai salah satu penyebab yang cukup berarti. Jika hal ini terus berlangsung dan seiring dengan peningkatan impor ditambah defisit neraca jasa maka akan terus terjadi defisit current account. Lebih lanjut hal ini akan menyebabkan terus terdepresiasinya nilai tukar rupiah terhadap dollar Amerika.

\subsection{Analisis Statistik dari Model dan Analisis Ekonomi Model (3.3)}

\section{Analisis Statistik:}

Hasil analisis Persamaan (3.3) menunjukkan bahwa pengaruh aliran modal swasta jangka pendek $\left(\mathrm{AMS}_{\mathrm{t}}\right.$ reduced form) terhadap laju inflasi $\left(\mathrm{LnIHK}_{\mathrm{t}}\right)$ signifikan pada taraf 10 persen. Pengaruh $\mathrm{AMS}_{t}$ reduced form yang signifikan tersebut menunjukkan bahwa aliran modal masuk dapat menambah jumlah uang beredar dan berpengaruh terhadap peningkatan laju inflasi di Indonesia.

Selanjutnya perubahan nilai tukar rupiah/US $\$\left(\mathrm{LnNT}_{\mathrm{t}}\right.$ reduced form $)$ dan pertumbuhan produk domestik bruto riil ( $\mathrm{LnPDB}_{\mathrm{t}}$ ) sangat berpengaruh signifikan terhadap laju inflasi pada taraf 5 persen.

Suku bunga Sertifikan Bank Indonesia $\left(\mathrm{SBI}_{\mathrm{t}}\right)$ berpengaruh signifikan terhadap laju inflasi pada taraf 5 persen. Pengaruh suku bunga SBI yang signifikan menunjukkan bahwa 
laju inflasi di Indonesia dipengaruhi juga oleh sisi permintaan selain dipengaruhi oleh sisi penawaran. Oleh karena itu ketika Bank Indonesia menaikkan suku bunga SBI, laju inflasi dapat tertekan. Sedangkan pengujian keseluruhan dari model (uji F) menunjukkan seluruh persamaan signifikan dalam menjelaskan variabel terikatnya. sehubungan dengan pengujian autokorelasi pada persamaan ini yang tidak meyakinkan, maka selanjutnya dilakukan pengujian loncatan (Run test). Berdasarkan hasil Run test, diperoleh nilai K (loncatan) sebanyak 13. Dengan asumsi $\mathrm{H}_{0}=$ tidak terdapat autokorelasi, pada tingkat kepercayaan 95 persen ternyata $\mathrm{K}$ berada di antara interval atau $\mathrm{H}_{0}$ diterima (lihat lampiran), sehingga dapat disimpulkan bahwa Persamaan (3.3) tidak mengandung serial korelasi.

\section{Analisis Ekonomi:}

Berdasarkan hasil analisis Persamaan (3.3) diperoleh hasil bahwa aliran modal swasta jangka pendek berpengaruh positif terhadap laju inflasi, yaitu jika aliran modal swasta jangka pendek bertambah US \$10 milyar (ceteris paribus), maka laju inflasi akan meningkat sebesar 0,40 persen. Bila lebih jauh dianalisis, hasil ini menunjukkan bahwa dengan bertambahnya nilai aliran modal swasta jangka pendek dapat menambah jumlah uang beredar, di mana secara teoritis peningkatan jumlah uang beredar cenderung meningkatkan laju inflasi. Keadaan ini dapat terjadi bila aliran modal masuk semata-mata disebabkan oleh menurunnya suku bunga internasional menjadi relatif sangat rendah. Tetapi yang terjadi di Indonesia pada pertengahan tahun 1997 dan di masa krisis, hal ini tidak terjadi. Walaupun tingkat suku bunga di Indonesia ditingkatkan cukup tinggi, tetapi modal jangka pendek terus mengalir ke luar negeri. Hal ini lebih diakibatkan oleh tidak kondusifnya situasi politik yang pada akhirnya menciptakan ketidaknyamanan iklim berinvestasi di Indonesia. Sehingga ketika terjadi krisis moneter yang notabene terjadi arus modal ke luar terutama yang berjangka pendek, inflasi tetap meningkat. Hal ini diperparah ketika modal tersebut mengalir ke luar negeri, output yang dihasilkan pun menjadi berkurang, karena kepercayaan produsen menurun. Pada akhirnya kejadian ini mengakibatkan inflasi yang cukup tinggi.

Meningkatnya laju inflasi ketika bertambahnya nilai aliran modal swasta jangka pendek, merupakan indikasi bahwa aliran modal masuk dalam bentuk penanaman modal jangka pendek tidak dimanfaatkan secara efektif untuk meningkatkan output domestik. Hal ini ditunjukkan oleh masih tingginya nilai impor barang dan defisit neraca jasa dibanding nilai ekspor barang, yang berarti belum terpenuhinya kebutuhan domestik. Sehingga hal ini memicu depresiasi nilai tukar rupiah/US \$ sebagaimana ditunjukkan oleh pengaruh perubahan nilai tukar rupiah/US \$ yang sangat signifikan terhadap laju inflasi.

Perubahan nilai tukar rupiah/US \$ berpengaruh positif terhadap laju inflasi. Jika nilai tukar rupiah terdepresiasi sebesar 1 persen (ceteris paribus), maka laju inflasi akan meningkat sebesar 0,72 persen. Pengaruh perubahan nilai tukar rupiah terhadap laju inflasi 
yang positif merupakan pass-trough effect dari barang-barang dan bahan baku impor yang harganya meningkat, sehingga mengakibatkan meningkatnya biaya produksi. Sebagaimana diketahui bahwa Indonesia belum bisa menghentikan ketergantungannya terhadap bahanbahan baku impor. Sehingga ketika terjadi depresiasi rupiah terhadap dollar Amerika, dibutuhkan dana yang cukup besar untuk melakukan produksi. Sehingga pada akhirnya akan meningkatkan harga barang-barang yang diproduksi. Hal ini sesuai dengan penelitian Muh. Ilham yang menyatakan bahwa perubahan nilai tukar rupiah berpengaruh sangat signifikan terhadap laju inflasi.

Pengaruh pertumbuhan produk domestik bruto riil terhadap laju inflasi menunjukkan arah yang positif, yang berarti jika produk domestik bruto riil tumbuh sebesar 1 persen (ceteris paribus), maka laju inflasi akan naik sebesar 0,46 persen. Pengaruh positif pertumbuhan produk domestik bruto riil terhadap laju inflasi, mengisyaratkan bahwa kenaikkan tingkat output riil tidak bisa meredam laju inflasi. Hal ini lebih dipengaruhi oleh perilaku masyarakat yang tidak optimis mengharapkan laju inflasi di masa yang akan datang akan menurun. Sehingga walaupun terjadi kenaikkan output riil, laju inflasi tetap meningkat. Untuk mengatasi laju inflasi dari sisi permintaan, maka melalui kebijakan Bank Indonesia dapat dilakukan dengan jalan menaikkan suku bunga Sertifikat Bank Indonesia. Berdasarkan hasil analisis menunjukkan bahwa suku bunga SBI berpengaruh negatif terhadap laju inflasi dengan nilai koefisien sebesar -0.005 . Pengaruh negatif tersebut mengisyaratkan bahwa bila Bank Indonesia meningkatkan suku bunga SBI sebesar 1 persen (ceteris paribus), maka laju inflasi menurun sebesar 0,005 persen. Seperti telah disebutkan di awal bahwa sertifikat Bank Indonesia merupakan salah satu instrumen kebijakan moneter, ketika terjadi inflasi terutama yang disebabkan oleh permintaan, sertifikat Bank Indonesia merupakan instrumen yang cukup efektif untuk mengendalikan inflasi tersebut. Hal ini bisa dijelaskan dengan mekanisme: ketika terjadi kelebihan permintaan yang diakibatkan oleh adanya peningkatan produk domestik bruto riil, yang berarti pula bahwa masyarakat memiliki pendapatan yang lebih dibandingkan dengan periode sebelumnya. Untuk menghindari terjadinya inflasi, maka ketika suku bunga sertifikat Bank Indonesia meningkat, yang berarti return yang bisa didapatkan oleh masyarakat juga akan meningkat (ceteris paribus). Sehingga uang masyarakat akan tertarik untuk membeli sertifikat Bank Indonesia. 


\section{REFERENSI}

Aliman, Tingkat Mobilitas Kapital: Sebuah Studi Empirik di Indonesia, Ekonomi dan Keuangan Indonesia Vol. XLIX no. 1, 2001

Copeland, Laurence S, Exchange Rates and International Finance, Addison-Wesley Publishing Company, 1988

Dornbusch, Rudiger and Stanley Fischer, Macroeconomics Fourth Edition, McGraw-Hill, Inc., 1987

Garibaldi, Pietro., Mora, Nada., Sahay, Ratna and Zettelmeyer, Jeromin, What Moves Capital to Transition Economies? IMF Staff Papers. Vol. 48 Special Issue. 2001

Gordon, J Robert, Macroeconomics Sixth Edition, Harper Collins College Publisher, 1993

Gudjarati, Damodar, Basic Econometric Third Edition, Mc Graw-Hill,1995

Ilham, Muh., Keterkaitan Aliran Modal Swasta Non Penanaman Modal Langsung Terhadap Perubahan Nilai Tukar dan Laju Inflasi di Indonesia, Tesis Program Pasca Sarjana, Universitas Padjadjaran.

International Financial Statistic (IFS)

Jhingan, M.L., Ekonomi Pembangunan dan Perencanaan, PT RajaGrafindo Persada, Jakarta, 1996

Krugman, Paul R and Osfeld M, Ekonomi Internasional, Teori dan Kebijakan, Harper Collins Publisher,1991

Kurniati, Yati, Kemungkinan Penerapan Kebijakan Arus Modal Jangka Pendek dan Dampaknya Bagi Stabilitas Nilai Tukar, Buletin Ekonomi Moneter dan Perbankan, Desember 2000

Laporan Tahunan BI 2000

Levi, Maurice D, Keuangan International Buku 2, McGraw-Hill Book Co, 2001

Mahyuddin, Moh Ikhsan, Pelarian Modal dari Indonesia: Estimasi dan Masalahnya, Ekonomi dan Keuangan Indonesia, Vol. 37, No. 1,1989

Mishkin, S Frederich, The Economics of Money Banking and Financial Market Fourth Edition, Harper Collins College Publisher, 1995

Nopirin, Ph.D, Ekonomi Internasional Edisi 3, BPFE Yogyakarta, 1995 
Parkin, Michael, Macroeconomics, Third Edition, Addison - Wesley International Edition, 1996

Rivera-Batiz, Francois L., and Luiz Pivera-Batiz, International Finance and Open Economy Macroeconomics, McMillan, 1985.

Salvatore, Dominick, International Economics Seventh Edition, John Wiley \& Sons, 1999

Syafaat, Nizwar, Pendugaan Parameter Persamaan Simultan Dengan OLS, 2SLS,LIML dan 3SLS, Jurnal Ekonomi dan Keuangan Indonesia, Volume XLIV No. 4, 1996

Tambunan, Tulus, Sumber Inflasi dan Kebijakan Kontraktif di Indonesia, Jurnal Ekonomi, Volume XLIV No. 1, 1996, LPEM-FE UI

Todaro, Michael P, Pembangunan Ekonomi di Dunia Ketiga, Edisi keempat, Erlangga, Jakarta

Widodo, Hg Suseno Triyanto Drs, Indikator Ekonomi; Dasar Perhitungan Perekonomian Indonesia, Kanisius, 1990 